\title{
REALISME DALAM KEBIJAKAN PENOLAKAN PENGUNGSI DAN MIGRAN OLEH HUNGARIA TAHUN 2015-2018
}

\author{
Angga Nurdin Rachmat
}

\begin{abstract}
Refugees and migrants became a big problem in Europe after World War II, this time refugees came from Middle East cause of recent conflict in the region. Hungary, geographically is the country became a gateway for refugees and migrants coming from the Middle East to go to Western and Northern European countries. Hungary has become a party to the 1951 Refugee Convention and 1967 Protocol which has the mandate to carry out the protection and fulfillment of the rights of refugees who come to their territory, especially in this case Hungary is serve as a transit country. However, the facts that occur are Hungary's refusal of the presence of refugees by issuing a series of policies that are considered controversial and inviting criticism from the European Union and other European countries. Referring to the reality, this study attempt to explain the reasons behind Hungary's rejection of refugees and migrants from the Middle East by the realism perspective. This research was conducted with a qualitative approach where data were collected through interviews and literature studies. This research found that policies issued by Hungary are based on national interests which are the basis of consideration used by a country in making policies according to the view of realism. The national interest is related to the interests of core values, middle range objectives and long range goals that want to be maintained or protected when faced with the arrival of refugees and migrants to Hungary.
\end{abstract}

Keywords: National Interest, Threat, Policy, Refugees Crisis.

\section{Latar Belakang}

Permasalahan pengungsi saat ini menjadi perhatian berbagai pihak, terkait dengan berbagai konflik, kekerasan, kemiskinan serta berbagai alasan lain di negara asal. Meskipun isu ini telah memperoleh tempat khusus dalam sistem PBB dengan menempatkan United Nations High Commissioner on Refugees (UNHCR) sebagai badan khusus yang menangani 
permasalah yang beroperasi sejak tahun 1950. Keberadaan UNHCR tidak dapat dilepaskan dari upaya untuk menggalang dan memperkuat kerjasama, khususnya diantara negara dalam mengatasi masalah pengungsi. Untuk memperkuat solidaritas dan tanggungjawab komunitas internasional pada tahun 1951 dibentuk Konvensi mengenai Pengungsi dengan para pihak ${ }^{1}$ sebagai pengemban hak dan kewajiban bagi/terhadap pengungsi.

Keberadaan UNHCR dan Konvensi 1951 mengenai Pengungsi tidak dapat dilepaskan dari pemahaman mengenai nilai universal dari nyawa dan martabat manusia, sebagai dasar bagi diskursus yang ditujukan untuk kepentingan keadilan dan kesetaraan dalam rangka menyeragamkan bagaimana nilai tersebut diaplikasikan diseluruh masyarakat (Viotti dan Kauppi, 1997 : 402). Pemahaman tersebut merujuk pada Hadi (2008: 5758) dimana nilai liberalisme meyakini terdapatnya kebaikan dalam diri manusia dan kerjasama sebagai muara untuk menyelesaikan permasalahan. Dimana dalam hal ini adalah itikad baik serta kerjasama dari para pihak dalam mengatasi isu pengungsi sebagai masalah bersama.

Namun, dalam kenyataannya Hungaria sebagai negara pihak dalam Konvensi Pengungsi 1951 saat menghadapi gelombang pengungsi yang berasal dari Timur Tengah tetap mengedepankan kepentingan negaranya. Kebijakan-kebijakan yang dikeluarkan oleh Hungaria tidak sama sekali mencerminkan nilai-nilai liberalisme yang mendsari penghormatan terhadap kemanusiaan dan martabat manusia. Wangke (2016) menggambarkan bahwa Pemerintah Hungaria membangun barikade kawat berduri dalam rangka menghalangi masuknya gelombang pengungsi, disamping itu Perdana Menteri Victor Orban memperlakukan pengungsi sebagai kriminal dengan melakukan penahanan. Disamping itu yang tidak kalah menjadi perhatian adalah dirancangnya sebuah Undang-Undang

${ }^{1}$ Para Pihak adalah penyebutan terhadap negara yang telah melakukan ratifikasi terhadap sebuah perjanjian internasional, khusus dalam tulisan ini adalah negara yang meratifikasi Konvensi

PBB tahun 1951 mengenai pengungsi. 
yang bertujuan menerapkan sanksi pidana kepada warga Hungaria yang memberikan bantuan dalam bentuk apapun terhadap para pengungsi tersebut. Perilaku tersebut sebagai upaya memposisikan pengungsi sebagai ancaman yang harus ditangkal atau dinetralisir dengan menggunakan pendekatan power yang terwujud dalam cara-cara represif dalam menangani gelombang pengungsi tersebut.

Kebijakan Hungaria terhadap pengungsi yang akan masuk ke negaranya menjadi fokus perhatian internasional serta menarik untuk diteliti. Tetenyi, Barczikay dan Szent-Ivanyi (2018) melakukan kajian secara kuantitatif terkait daya tarik Hungaria sebagai tujuan dari migran dengan motif ekonomi. Penelitian-penelitian yang mengangkat permasalahan terkait dengan kebijakan Hungaria terhadap pengungsi khususnya yang berasal dari Timur Tengah dari sudut pandang pengambilan kebijakan telah dilakukan oleh Poli (2017), Ahmad (2018). Sementara Pradana (2018), Cantat dan Rajaram (2018) melihat adanya upaya untuk menggunakan politik identitas dalam rangka menghalangi masuknya pengungsi di Hungaria. Berdasarkan penelitian-penelitian terdahulu, belum ada yang menjelaskan perilaku Hungaria sebagai aktor negara dalam Hubungan Internasional dengan menggunakan pendekatan realisme dalam menghadapi isu pengungsi yang berasal dari Timur Tengah.

Beranjak dari permasalahan serta tinjauan kepustakaan diatas, artikel ini akan menawarkan diskusi lebih mendalam atas pertanyaan Bagaimana realisme mendasari kebijakan pemerintah Hungaria dalam merespon gelombang pengungsi yang berasal dari Timur Tengah? Beranjak dari pertanyaan tersebut tulisan dalam artikel ini akan berusaha untuk mengidentifikasikan nuansa realisme dalam kebijakan yang dikeluarkan oleh Hungaria sebagai negara pihak dalam Konvensi Pengungsi 1951 dan Protokol 1967 dalam menghadapi gelombang pengungsi yang berasal dari Timur Tengah. Penulisan artikel ini menggunakan metode kualitatif dimana data primer penelitian diperoleh melalui wawancara dengan Duta Besar Hungaria untuk Indonesia dan Pakar dari Pusat Kajian Eropa 
Universitas Indonesia serta didukung oleh data sekunder yang berasal dari berbagai dokumen yang terkait dengan realisme sebagai dasar perspektif yang digunakan, kondisi Hungaria serta fenomena permasalahan pengungsi di Hungaria.

\section{Realisme: Pencapaian dan Perlindungan Kepentingan Nasional}

Realisme menjadi sebuah pendekatan dalam analisis hubungan internasional yang telah memiliki akar kuat, khususnya dalam mendasari setiap pengambilan keputusan yang dilakukan oleh pengambil kebijakan didalam negara. Dalam konteks penelitian ini kebijakan-kebijakan yang dikeluarkan oleh Hungaria dalam menghadapi permasalahan pengungsi yang berasal dari Timur Tengah tidak dapat dilepaskan dari rasionalitas para pengambil kebijakan yang didasarkan pada prudence (untung-rugi). Meskipun seperti yang telah dijelaskan sebelumnya bahwa Hungaria adalah Pihak dalam Konvensi mengenai pengungsi yang didasarkan pada nilai ideal dalam hubungan internasional namun pada kenyataannya seperti yang dikemukakan oleh Hadi (2008 : 62) bahwa dalam hubungan internasional memiliki sifat dasar mengenai kekuasaan yang akan tercermin melalui pencapaian kepentingan nasional dari pada ideal-ideal yang disepakati.

Kepentingan nasional sebagai dasar perilaku negara sejalan dengan penyataan Machiavelli yang dikutip dari Bainus dan Rachman (2018: 109), Seabury (1963: 86) bahwa kepentingan nasional akan senantiasa menjadi justifikasi serta dasar pertimbangan negara dalam berperilaku serta pengabaian terhadap moralitas oleh para pengambil kebijakan dalam urusan-urusan kenegaraan. Moralitas sebuah negara yang tercermin dalam kepatuhan terhadap hukum maupun perjanjian yang diikuti, khususnya dalam penelitian ini mengenai pengungsi telah jauh dikesampingkan. Negara dalam menghadapi permasalahan pengungsi mengedepankan power melalui instrumen pemaksa yang diimplementasi melalui kebijakankebijakan represif terhadap pengungsi. Bagi negara kedaulatan merupakan 
harga mati sehingga elemen-elemen power yang dimilikinya digunakan untuk tetap menjamin kedaulatan tersebut dari ancaman pihak eksternal (Burchill, 2005: 69).

Dalam pembahasan di artikel ini, kepentingan nasional yang menjadi tujuan untuk dicapai dan dipertahankan oleh Hungaria yang tercermin dalam kebijakan-kebijakan terhadap pengungsi dari Timur Tengah akan dirujuk dari K.J Holsti. Holsti (1983: 129-134) menyatakan bahwa terdapat tiga macam kepentingan nasional dari sebuah negara yakni terkait dengan core value, middle range objective dan long range objective. Penjelasan lebih lanjut mengenai kepentingan nasional Holsti tersebut dipaparkan oleh Srivatava dan Joshi (2005: 12-15). Core Value akan terkait dengan upaya dari sebuah negara untuk menjamin eksistensinya sehingga menjadi sesuatu yang tidak dapat dikompromikan terkait dengan keamanan nasional dan pembangunan ekonomi. Sementara Middle Range Objective merupakan upaya dari sebuah negara untuk memperkuat posisinya dalam politik internasional yang terkait dengan kerjasama internasional, citra negara dan akomodasi kepentingan domestik. Terakhir adalah terkait dengan long range objective merupakan upaya pencapaian nilai-nilai ideal serta cita-cita dari sebuah negara baik dalam politik internasional maupun pada ranah domestik.

\section{Kebijakan Hungaria Terhadap Pengungsi dan Migran}

Secara geografis Hungaria yang terletak di tengah benua Eropa menjadikan negara ini gerbang bagi para pengungsi dan migran untuk masuk ke negara-negara Eropa Barat. Tidak dapat dipungkiri sebagai negara transit pada kenyataannya merujuk pada data dari penelitian Attila, Zgut dan Juhasz (2015) bahwa pengungsi yang mengajukan aplikasi suaka mencapai 1.781 orang, merupakan yang tertinggi diantara negara Uni Eropa lainnya. Meskipun menjadi negara yang meratifikasi Konvensi Pengungsi 1951 dan Protokol 1967 serta hanya menjadi negara transit namun hal ini tidak membuat Hungaria menjadi negara yang 
mengakomodir kehadiran dari para pengungsi dan migran di negaranya. Berbagai kebijakan dikeluarkan oleh Hungaria sebagai upaya negara ini untuk menolak kehadiran para pengungsi dan migran di negaranya ditengah kencaman yang dilontarkan oleh berbagai pihak termasuk Uni Eropa (UE), UNHCR maupun negara lain.

Kebijakan sebuah negara akan tercermin berdasarkan pernyataan yang diberikan oleh kepala pemerintahan, dimana dalam hal ini penolakan terhadap pengungsi dan migran dari Hungaria secara jelas dan tegas dilihat dari pernyataan-pernyataan yang dikeluarkan oleh Victor Orban sebagai Perdana Menteri yang dikutip oleh berbagai media baik di Eropa maupun Internasional. Pernyataan tersebut merupakan penegasan dari sikap negaranya yang tidak menginginkan kehadiran dari para pengungsi tersebut di Hungaria dengan berbagai alasan. Tentu saja pernyataanpernyataan ini sangat kontroversial karena sama sekali tidak mengindahkan nilai-nilai kemanusiaan yang seharusnya diusung dalam krisis pengungsi dan migran tersebut.

Pembangunan pagar disepanjang perbatasan Hungaria dan Serbia oleh pemerintah Hungaria yang ditujukan untuk menghalau masuknya pengungsi dan migran menjadi sorotan dunia internasional. Pada tahun 2017 Hungaria kemudian membangun pagar yang dialiri aliran listrik, dilengkapi dengan sensor panas, kamera dan pengeras suara serta dijaga oleh polisi di Hungaria bagian selatan. Hungaria telah mengalikasikan sekitar 250 juta Euro untuk membangun pagar di sepanjang wilayah perbatasan yang menjadi jalur masuk pada pengungsi dan migran tersebut, bahkan upaya untuk mengalau para pengungsi dan migran ini telah menghabiskan biaya hingga mendekati 1 Miliar Euro (Purnama, 2015).

Dalam rangka melegitimasi penolakan terhadap pengungsi dan migran ini, pemerintah Hungaria kemudian mengadakan referendum yang melibatkan masyarakat Hungaria. Tujuan dari referendum ini adalah untuk memberikan pilihan kepada masyarakat apakah akan menerima atau menolak pembagian Kuota Pengungsi yang diamanatkan oleh UE kepada 
para anggotanya. Hasilnya 92\% masyarakat Hungaria menolak dan 8\% menyatakan setuju (Tomkiw, 2018). Dengan demikian maka, pemerintah Hungaria memiliki legitimasi untuk menolak pengungsi dan migran tersebut untuk masuk ke negaranya.

Perlakukan yang diberikan kepada pengungsi dan migran yang datang untuk melintas tidak kalah kontroversial, dimana para pengungsi dan migran ditempatkan dalam sebuah kamp selayaknya tahanan dengan pengawasan ketat. Kondisi semakin buruk saat tidak adanya bantuan kebutuhan pokok yang diberikan kepada para pengungsi, hal ini menjadi lebih sulit saat datangnya musim dingin. Tidak sampai disana para pengungsi juga diperlakukan dengan tidak manusiawi, banyak pengungsi yang mengalami pemukulan bahkan mengalami kriminalisasi. Banyak pengungsi yang kemudian menjalani penahanan dan masuk kedalam penjara akibat tindakan-tindakan mereka berusaha untuk masuk dan melintasi wilayah Hungaria. Tidak hanya ditujukan pada para pengungsi, pemerintah Hungaria juga mengeluarkan Undang-Undang yang akan menghukum warga Hungaria atau siapapun yang memberikan bantuan kepada para pengungsi yang berada di Hungaria. Dengan sanksi tersebut maka warga Hungaria yang ingin memberikan bantuan kepada para pengungsi menjadi terhalang karena khawatir akan sanksi pidana yang akan dituduhkan pada mereka.

\section{Mempertahankan Stabilitas Keamanan dan Akses Ekonomi sebagai Core Value}

Eropa mengalami permasalahan keamanan serius seiring dengan berbagai serangan teror yang melanda beberapa negara dikawasan ini, seperti yang terjadi di Perancis, Jerman dan Inggris. Serangan ini dilakukan oleh para pelaku yang terafiliasi dengan kelompok Islamic State of Iraq and Syria (ISIS) merupakan migran ataupun keturuan migran. Sebagai contoh berdasarkan fakta yang ditemukan menunjukan bahwa pelaku teror di Jerman merupakan pengungsi dari Suriah dan migran yang berasal dari 
Tunisia (Wardianto, 2018). Kondisi ini tentu saja semakin memperkuat kecurigaan terhadap masyarakat Muslim serta pengungsi dan migran yang berasal dari Timur Tengah ditengah Islamophobia yang masih kental melekat pada pemikiran masyarakat Barat, khususnya di Eropa.

Terjadinya arus pengungsi yang berasal dari Timur Tengah, khususnya Suriah membawa kekhawatiran tersendiri bagi negara-negara Eropa. Kekhawatiran ini terkait dengan potensi adanya anggota maupun simpatisan ISIS yang berada ditengah-tengah pada pengungsi tersebut. Kekhawatiran ini pun dirasakan oleh Hungaria, dimana penolakan negara ini terhadap kebijakan pembagian kuota pengungsi menjadi bukti bahwa negara ini menempatkan kehadiran pengungsi di negara mereka baik hanya untuk melintas maupun mengajukan aplikasi suaka menjadi ancaman terhadap keamanan nasionalnya. Prioritas tersebut sejalan dengan pernyataan Duta Besar yang menyatakan bahwa "setiap negara Eropa harus dapat melindungi dirinya sendiri, juga berhati-hati terhadap setiap orang yang masuk ke negaranya" (Pach, Wawancara, 31 Juli 2018) tidak terkecuali Hungaria. Perilaku kehati-hatian yang ditunjukan oleh Hungaria tidak terlepas dari kecurigaan yang akan melandasi perilaku sebuah negara sebagai sebuah unit politik yang independen dalam menentukan kebijakan. Dimana terkait dengan masalah pengungsi tersebut Hungaria tersebut sejalan dengan perspektif realisme yang menempatkan keamanan nasional sebagai isu utama dan menempati tempat teratas disamping isu-isu lainnya (Viotti dan Kauppi, 1999: 7 dan Pareira, 1999: 103). Oleh karena dalam pandangan ini, Hungaria mengesampingkan isu kemanusiaan dalam memandang masalah pengungsi karena lebih mengedepankan isu terkait dengan keamanan nasional yang ingin dilindungi.

Disamping permasalahan terorisme ancaman yang kemudian muncul adalah kejahatan transnasional, yang merupakan ancaman nyata terhadap keamanan domestik sebuah negara. Fakta ini pun sejalan dengan apa yang dilakukan oleh Pemerintah Hungaria yang mengaitkan antara 
migrasi, terorisme dan pengangguran (Juhasz, Hunyadi dan Zgut, 2015: 25). Penanganan akan hal ini dapat dilakukan dengan melakukan pengetatan terhadap kontrol perbatasan, penangguhan visa dan pengaplikasian verifikasi identitas. Kebijakan tersebut tentu mengundang kecaman baik dari Uni Eropa maupun Organisasi kemanusiaan karena menganggap bahwa apa yang dilakukan oleh Hungaria bertentangan dengan prinsip-prinsip Hak Azasi Manusia dan Konvensi Pengungsi 1951 dan Protokol 1967. Namun hal tersebut merupakan bagian dari otoritas yang dimiliki Hungaria sebagai sebuah negara.

Hungaria memiliki pertimbangan tersendiri dalam menghadapi permasalahan yang sedang dihadapi. Permasalahan yang dihadapi Hungaria adalah besarnya gelombang pengungsi yang datang ke wilayah mereka, seperti informasi yang diperoleh dari wawancara dengan Pach (31 Juli 2018) "situasi ini akan terkait dengan kontrol terhadap perbatasan, administrasi karena pengungsi tidak memiliki dokumen apapun untuk memenuhi prosedur agar dapat diizinkan masuk". Dengan demikian maka tidak ada mekanisme verifikasi untuk memastikan identitas dari para pengungsi tersebut, jika pun dilakukan verifikasi akan memakan waktu yang cukup lama. Karena tidak dapat dipungkiri seperti yang telah merujuk pada wawancara dengan Fadli (28 Juli 2018) bahwa para pengungsi kadang bukan sepenuhnya berniat datang untuk mengungsi, mereka memiliki tujuan tertentu dalam konteks ini di Eropa, namun tak dapat dipungkiri bahwa pengungsi ini banyak juga yang melakukan kekerasan, perampokan, tindak asusila, terhadap masyarakat lokal. Oleh karena itu penolakan Hungaria terhadap para pengungsi adalah sebuah bagian dari independensi dari Hungaria sebagai sebuah negara dalam menjalankan kewenangan untuk mengatur kehidupan di wilayah teritorialnya (Bertelson, 2006: 465; Sorensen, 2011: 111). Independensi dan kewenangan untuk melindungi masyarakatnya dan wilayah teritorialnya dari berbagai ancaman yang datang termasuk yang diasumsikan berasal dari para pengungsi dan migran tersebut. 
Bagi realis, negara merupakan entitas yang akan mengedepankan egoisme dengan senantiasa mengejar kepentingan sendiri dan bertindak berdasarkan pertimbangan rasional (Mitchell Ryan, 2017: 422). Karakter ini yang kemudian dapat dilihat dari Hungaria terkait dengan penolakan terhadap pengungsi dan migran yang datang ke negaranya. Pengungsi dalam jumlah besar yang datang ke Hungaria tentu akan menimbulkan konsekuensi ekonomi baik dalam jangka pendek maupun jangka panjang. Pada jangka pendek Hungaria yang tengah mengalami perbaikan ekonomi pasca krisis akan menanggung beban fiskal untuk alokasi anggaran bagi pencari suaka sebesar 0,1\% dari PDB (OECD, 2015). Hal ini terkait bahwa Hungaria harus menyediakan perawatan kesehatan, rumah sementara, makanan, obat-obatan dan segala kebutuhan yang diperlukan oleh pengungsi. Dibandingkan dengan mengalokasikan dana untuk pengungsi dan migran tersebut, Hungaria akan lebih memilih mengalokasikan dana tersebut untuk pemulihan dan pembangunan ekonomi di negaranya.

Pada aspek jangka panjang, Hungaria memiliki kekhawatiran terhadap ketersediaan lapangan pekerjaan. Kondisi ini terkait dengan para pengungsi dan migran tersebut tidak hanya menjadikan Hungaria sebagai negara transit, namun juga negara tinggal yang dibuktikan dengan peningkatan aplikasi pemohon suaka dari individu yang berasal dari Timur Tengah tersebut. Hungaria sendiri masih memiliki tingkat pengangguran yang cukup tinggi yakni sekitar 8\% dibandingkan negara UE lainnya (International Business Times, 2015). Kehadiran dari pengungsi dan migran tersebut akan meningkatkan kompetisi dalam memperebutkan lapangan pekerjaan dengan warga asli Hungaria. Kekhawatiran ini didasarkan pada karakteristik dari para pengungsi dan migran yang memiliki etos kerja diatas rata-rata orang Hungaria serta dapat dibayar murah. Atas dasar tersebut, Perdana Menteri Hungaria menyebutkan bahwa para pengungsi dan migran tersebut akan mengambil pekerjaan dari orang-orang Hungaria. Dengan demikian sudah menjadi kewajiban Hungaria sebagai sebuah 
negara untuk menyediakan dan mengamankan akses ekonomi dari warga negaranya.

\section{Middle Range Objective: Eksistensi Hungaria di Kawasan Eropa}

Krisis Pengungsi yang melanda Eropa, menjadi perhatian dari Uni Eropa sebagai Organisasi Kawasan untuk turut menyelesaikan permasalahan yang dihadapi oleh anggota-anggotanya tersebut. Dalam menyikapi krisis tersebut Uni Eropa mengeluarkan berbagai kebijakan menambahkan sumber daya, membentuk badan khusus untuk menangani permasalahan tersebut, memperkenalkan Penjaga Pantai dan Perbatasan Uni Eropa serta mencoba mengharmoniskan prosedur penerimaan pencari suaka diantara negara-negara anggotanya (Bordignon dan Moriconi, 2017: 2). Pada aspek implementasi, UE mengeluarkan kebijakan pembagian beban pengungsi dan migran ini kepada negara-negara anggotanya, dimana negara-negara UE harus menerima pengungsi dan migran melalui skema relokasi berdasarkan kuota yang ditetapkan oleh UE. Status UE sebagai organisasi kerjasama dan bukan supranasional menjadikan kebijakan tersebut tidak otomatis diterima oleh anggotanya sehingga terdapat negara yang mendukung kebijakan ini dan tidak sedikit yang melakukan penolakan. Salah satu negara yang dengan tegas melakukan penolakan secara tegas dan jelas adalah Hungaria.

Hungaria menjadi anggota dalam Uni Eropa sejak tahun 2004, keanggotaan tersebut menandai era baru dalam kehidupan politik dan khususnya ekonomi Hungaria. Meskipun demikian, pada tahun 2014 sejak Victor Orban berkuasa kebijakan Hungaria mengarah pada kecenderungan untuk berseberangan dengan kebijakan yang dibuat oleh Uni Eropa. Sikap Hungaria menolak kehadiran pengungsi dan migran seperti yang diangkat dalam tulisan ini merupakan salah satu bentuk resistensi yang cukup jelas dan kuat membawa pesan dalam menekankan peran penting independensi Hungaria sebagai negara. Resistensi terhadap UE dipandang sebagai 
tindakan yang mengedepankan strategi dan kepentingan nasional serta mengukuhkan dominasi dari para pembuat kebijakan di mata para warga negaranya (Benkova, 2017: 1). Bagi Hungaria penolakan terhadap kebijakan UE dalam permasalahan pengungsi dan migran serta kecaman yang kemudian diterima dari UE menunjukan bahwa institusi internasional tidak menjadi bagian penting dalam politik domestik maupun internasional Hungaria. Terlebih Hungaria melalui PM Victor Orban senantiasa menyerang negara-negara yang membuka diri terhadap pengungsi dan migran seperti Jerman dan Swedia yang juga anggota dari UE.

Perilaku yang ditunjukan oleh Hungaria sejalan dengan Mearsheimer (1994: 7) yang menyebut bahwa institusi internasional hanya penting dalam hal tertentu dan memiliki dampak minimal terhadap perilaku negara. Dengan demikian maka, UE dalam pandangan Hungaria tidak menyediakan keuntungan (prudence) untuk menyelesaikan permasalahan pengungsi, sehingga Hungaria tidak mematuhi kebijakan yang dikeluarkan oleh UE untuk menerima pengungsi dan migran di negaranya. Hungaria dalam perilaku penolakan terhadap pengungsi dan migran merupakan sebuah upaya untuk mengukuhkan eksistensi negara di kawasan Eropa dan di dalam UE. Eksistensi terkait dengan urgensi dari tindakan unilateral negara dibandingkan dengan tindakan kolektif dalam sebuah organisasi dengan pertimbangan prudence tersebut.

Bagi Hungaria, Uni Eropa merupakan sebuah mekanisme yang tidak perlu untuk diindahkan jika bertentangan dengan kepentingan yang diusung oleh negaranya. Penentangan Hungaria terhadap kebijakan penerimaan dan pembagian beban pengungsi dan migran UE sebagai bagian dari politik luar negeri yang ditujukan di kawasan dan sekaligus organisasi kawasan. Dengan demikian maka, upaya untuk mengukuhkan atau mencapai eksistensi negara didalam kawasan maupun organisasi tersebut sejalan dengan pandangan realisme (Ozkan dan Cetin, 2016: 89) dimana negara akan menjadi aktor utama dan lebih rasional. Hungaria dalam permasalahan ini menganggap bahwa UE tidak melandaskan 
pertimbangan rasional dalam kebijakan terkait dengan pengungsi dan migran. Dengan demikian maka Hungaria berkeyakinan bahwa kebijakan tersebut tidak akan membawa banyak perubahan terhadap krisis pengungsi dan migran yang terjadi di negaranya bahkan hanya akan membawa masalah baru.

\section{Long Range Objective: Melindungi dan Memproyeksikan Nilai-Nilai Kristen di Hungaria}

Hungaria sebagai sebuah negara memiliki nilai-nilai atau tujuan baik dalam ranah internasional maupun domestik yang ingin diraih maupun dipertahankan yang tercantum dalam konstitusinya. Terkait dengan permasalahan yang diangkat dalam penelitian ini terdapat beberapa dasar khususnya yang menjadi nilai-nilai atau tujuan yang hendak dipertahankan atau dilindungi dengan adanya arus pengungsi dan migran ke Hungaria. Dalam pembukaan konstitusi Hungaria, sangat jelas mencantumkan nilai-nilai Kristen di dalamnya dimana salah satunya adalah pengakuan terhadap nilai tersebut dalam membangun negaranya (We recognise the role of Christianity in preserving nationhood). Disamping itu pemerintah Hungaria memiliki kewajiban dalam rangka melindungi warisan bahasa dan budaya sebagai identitas nasional yang hidup di Hungaria beserta sumber daya alam dan buatan yang berada di wilayah Basin Carpatia. Penolakan terhadap pengungsi dan migran khususnya yang berasal dari Timur Tengah merupakan upaya yang dilakukan oleh Hungaria sebagai implementasi atas pembukaan konstitusi pada dua poin tersebut.

Fenomena perpindahan yang terkait dengan pengungsi maupun migran yang menuju ke Eropa, khususnya yang melintasi Hungaria tidak hanya melibatkan perpindahan manusia secara fisik namun juga identitas yang menyertainya seperti nilai, adat, budaya dan lain sebagainya. Terkait dengan asal dari para pengungsi yang sebagian besar berasal dari Timur Tengah, memiliki identitas islam yang berbeda bahkan dianggap akan bertolak belakang dengan nilai-nilai yang ada di masyarakat Hungaria. 
Kondisi ini diperburuk dengan fenomena Xenophobia yang melanda masyarakat Eropa, seperti yang dijelaskan Vranska, et.al (2017) bahwa xenophobia dipicu dengan terjadinya krisis pengungsi yang meningkat setiap tahun, dimana pada tahun 2014 terdapat 283.500 orang secara ilegal melalui perbatasan Schengen sementara tahun 2015 diprediksi 1 juta orang.

Keberadaan orang asing, akan diposisikan sebagai ancaman bagi Hungaria dan juga masyarakatnya merujuk pada fakta historis yang diperoleh saat wawancara dengan Fadli (26 Juli 2018) bahwa Revolusi 1945 yang terjadi di negara ini yang membuat Hungaria menjadi sangat tertutup dengan orang asing demikian pun dengan para pengungsi tersebut. Dengan demikian maka pemerintah Hungaria dalam hal ini harus melakukan tindakan untuk tetap mempertahankan stabilitas masyarakat yang tertutup tersebut dengan tidak melakukan penerimaan terhadap para pengungsi dan migran. Penerimaan pengungsi dan migran tersebut akan memaksa masyarakat Hungaria untuk terbuka, dan dalam prosesnya hal ini akan sangat rentan dengan konflik sosial diantara masyarakat.

Pada tataran internasional tujuan atau cita-cita dari Hungaria seperti yang tercantum dalam pembukaan konstitusinya menyatakan bahwa negara ini sejak seribu tahun lalu merupakan bagian dari Kristen Eropa. Hungaria akan tetap berupaya untuk mempertahankan dan berusaha untuk mencapai hal tersebut dengan tidak melakukan asimilasi dengan budaya maupun nilai asing yang dibawa oleh para pengungsi dan migran khususnya berasal dari Timur Tengah. Asimilasi yang terjadi jika pengungsi dan migran diterima oleh Hungaria akan membawa negara ini pada hambatan untuk mencapai cita-cita tersebut karena akan menimbulkan perubahan pada identitas nasional Hungaria. Dengan demikian penolakan Hungaria terhadap pengungsi dan migran merupakan sebuah tindakan pencegahan dalam rangka mempertahankan kemurnian identitas Kristen Eropa yang dipegang teguh oleh Hungaria. 


\section{Kesimpulan}

Berdasarkan pembahasan yang telah dilakukan artikel ini melihat bahwa kebijakan-kebijakan yang diambil oleh Hungaria dalam menghadapi arus pengungsi dan migran dari Timur Tengah dilandasi oleh realisme yakni terkait upaya untuk mempertahankan dan melindungi kepentingan nasionalnya. Merujuk pada kepentingan nasional yang dikemukakan oleh K.J Holsti, Hungaria berusaha untuk mempertahankan dan melindungi kepentingan nasional vital (core value) yang terkait dengan ancaman terorisme dan kejahatan transnasional serta akses ekonomi, jangka menengah (middle range objective) terkait dengan upaya untuk mengukuhkan eksisten negara saat berhadapan dengan UE sebagai organisasi internasional dan kepentingan nasional jangka panjang (long range goals) terkait dengan pencapaian identitas negara Kristen baik dalam tataran domestik maupun internasional/ regional. Dengan demikian maka penolakan pengungsi dan migran yang dilakukan oleh Hungaria merupakan cerminan dari sikap negara yang didasarkan pada realisme.

\section{DAFTAR PUSTAKA}

Ahmad. 2018. Analisa Kebijakan Hungaria Dalam Menolak Menerima Pengungsi Asal Suriah Pada Krisis Pengungsi Eropa. Skripsi Universitas Muhammadiyah Malang : Malang. Diakses dari http://eprints.umm.ac.id/39194/

Attila, Hunyadi, Bulcsu, Zgut, Edit Juhasz, Focus on Hungary : Refugees, Asylum and Migration. Prague: Heinrich-Boll-Stiftung, 2015.

Bartelson, Jens, 2006. The Concept of Soverignty Revisited. The European Journal of International Law, Vol. 17 No.2 hlm. 463-474.

Benkova, Livia. 2017. Europe's Response to the Migration Crisis. AIES : Hainburg.

Bordignon, Massimo dan Moriconi, Simone. 2017. The Case for a Common European Refugee Policy. Policy Contribution. Issue. 8 hlm 1-13. 
Burchill, Scott. 2005. The National Interest in International Relations Theory. Palgrave Macmillan : New York.

Cantat, Celline dan Rajaram, Prem Kumar. The Politics of Refugee Crisis in Hungary : B/ordering the Nation and Its Others dalam Menjivar, Cecilia, Ruiz, Marie dan Ness, Immanuel ed. 2018. The Oxford Handbook of Migration Crises. Oxford University Press : Oxford.

Fadli, Ahmad Fighi. Interview. 2018. Krisis Pengungsi di Eropa dan Hungaria. Sekolah Kajian Stratejik Global, Universitas Indonesia, Depok.

Hadi, Shaumil. 2008. Third Debate dan Kritik Positivisme Ilmu Hubungan Internasional, Jalasutra: Yogyakarta \& Bandung.

Holsti, K.J, 1983. International Politics : Framework for Analysis, PranticeHall : New Jersey.

International Business Times. 2015. Syrians Take Forest Paths From Serbia Into Hungary To Avoid Police Detection. (online) diakses dari http:/ / www.ibtimes.com/syrians-take-forest-paths-serbia-hungaryavoid-policedetection-2092725

Mearsheimer, Jhon J. 1994. The False Promise of International Institutions, International Security, Vol. 19 No. 1 hlm 5-49.

OECD. "How Will the Refugee Surge Affect the European Economy?". (8 November 2015) Internet, 12 Agustus 201, http:/ / www.oecd.org/migration/How-will-the-refugee-surge-affectthe-European-economy.pdf

Ozkan, Cetin dan Cetin, Hakan Cem. 2016. Realist and Liberal Position on the Role of International Organization in Maintaining World Order. European Scientific Journal, Vol. 12 No. 17 hlm 85-96.

Pach, Judit. Interview. 2018. Dinamika Politik Hungaria dalam Menghadapi Pengungsi dan Migran. Kedutaan Besar Kerajaan Hungaria untuk Indonesia, Jakarta. 
Pareira, Andreas H. 1999. Negara dalam Studi Hubungan Internasional : Perubahan dan Kesinambungan dalam Pareira Andreas H. ed. Perubahan Global dan Perkembangan Studi Hubungan Internasional, Bandung : Aditya Bakti.

Poli, Masdalena E. 2017. Kebijakan Hungaria Terhadap Krisis Pengungsi di Kawasan Eropa. Skripsi Universitas Hasanudin : Makassar. Diakses dari http:/ / repository.unhas.ac.id/handle/123456789/26787

Pradana, Aldoreza. 2018. "Identitas Nasional : Penggunakan Politik Identitas dalam Gelombang Pengungsi 2015 di Hungaria. ISS Brief Issue $\quad 03 . \quad \mathrm{Hlm} \quad 1-10 . \quad$ Diakses dari https://simpan.ugm.ac.id/s/uZRcLR2J2QrtJqV\#pdfviewer

Purnama, Crystal Liestia. 2018. Cegah Migran Ilegal Hungaria Bangun Pagar Canggih Beraliran Lisrik, Republika (Internet) 22 Juli 2018, diakses dari

https://www.republika.co.id/berita/internasional/global/17/03/03

/om7xfs359-cegah-migran-ilegal-hungaria-bangun-pagar-canggihberaliran-listrik

Seabury, Paul. 1963. Power, Freedom and Diplomacy : The Foreign Policy of the United States of America. Random House : New York.

Sorensen, George. Big and Important Things in IP : Struktural Realism and the Neglect of Changes in Statehood dalam Booth, Ken. 2011. Realism in World Politics. New York : Routledge.

Srivastava, L.S dan Joshi, V.P. 2005. International Relations [From 1914 to Present Day], Krishna Prakashan Media : Meerut.

Tetenyi, Andras, Barrczikay, Tamas dan Szen-Ivanyi, Balazs. 2018. "Refugees, not Economc Migrant - Why do Asylum-Seekers Register in Hungary?”, International Migration, Special Issue Article. hlm 1-18.

Viotti, Paul R dan Kauppi, Mark V. 1999. International Relations Theory : Realism, Globalism and Beyond, London : Allyn and Bacon. 
Vranska, Ivana, et.all. 2017. Xenophobia, The Cause of Terrorism in a Democratic Society, Vol.7, No. 4.

Wangke, Humprey. 2016. Krisis Migran dan Masa Depan Integrasi Eropa, Info Singkat Hubungan Internasional, Vol. 8 No.3 (Februari) hlm 5-8.

Wardianto, Gloria K. 2018. Bom Bunuh Diri di Ansbach Serangan ISIS Pertama di Jerman?, diakses dari http://international.kompas.com/read/2016/07/26/06000052/Bo m.Bunuh.Diri.di.Ansbach.Serangan.Pertama.ISIS.di.Jerman 